\title{
ANALYSis Of InNOVATION FACTORS At JoInt Stock COMPANIES ON EMerging MARKets ApPlying Strategic Planning MODEL
}

\author{
Borocki, J., DJAKovic, V., Buncic, S. \& Mitrovic, S.
}

Abstract: The aim of the presented study is to give contribution to the efforts that are being made to analyze the possible differences between joint stock companies and other companies from the research sample, regarding the selected innovation factors. In a research process modified SPACE ((Strategic Position and Action Evaluation) analysis for defining strategic position of the company was used. In the survey, the sample consist of the selected countries from SEE region, which are in the transitional phase. The results show that there are certain differences between joint stock companies and other companies in the sample, in terms of the selected factors of innovative enterprises, isolated from modified SPACE model in strategic planning. To determine these potential differences, factor analysis and hierarchical cluster were used, as appropriate stat. method.

Key words joint stock companies, innovation factors, cluster analysis, SPACE analysis, emerging markets
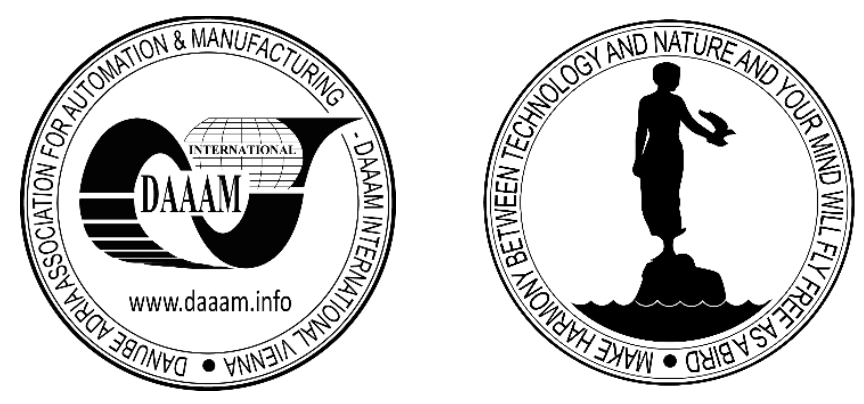

Authors' data: Assoc. Prof., Borocki, J[elena]*, Assist. Prof. Djakovic, V[ladimir]*, Full Prof., Buncic S[onja]*, Assist. Prof. Mitrovic S[lavica]*, *University of Novi Sad, Faculty of Technical Sciences, Department of Industrial Engineering and Management, D. Obradovic Square 6, 21000 Novi Sad, Republic of Serbia, borocki@uns.ac.rs, v_djakovic@uns.ac.rs, buncics@uns.ac.rs, mslavica@uns.ac.rs

This Publication has to be referred as: Borocki, J[elena]; Djakovic, V[ladimir]; Buncic, S[onja] \& Buncic, S[lavica] (2016). Analysis of Innovation Factors at Joint Stock Companies on Emerging Markets Applying Strategic Planning Model, Chapter 33 in DAAAM International Scientific Book 2016, pp.361-374, B. Katalinic (Ed.), Published by DAAAM International, ISBN 978-3-902734-09-9, ISSN 1726-9687, Vienna, Austria

DOI:10.2507/daaam.scibook.2016.33x 


\section{Introduction}

In the conditions of global economic crisis, the uncertainty of the operation of contemporary companies is conditioned by dynamic and complex environment resulting in new directions in the operation. The growing importance of the emerging markets is now well documented (Enderwick, 2008; Hoskisson et al., 2000). Emerging markets are low-income and with rapid-growth, while using economic liberalization as their primary engine of growth. Thus, an emerging market can be defined as a market that satisfies two criteria: a rapid pace of economic development, and government policies favouring economic liberalization and the adoption of a free-market system (Arnold \& Quelch, 1998). In recent years, strengthening of the market mechanisms through liberalization, stabilization, and the encouragement of private enterprise was carried out in emerging markets of Serbia, Bosnia, and Montenegro. Compared with the developed markets, emerging markets are characterized by reforms of the financial market, frequent internal and external financial shocks (i.e. political risk, economic risk, and financial risk), frequent changes of the credit rating, fluctuation of the foreign currency courses, high level of insider trading, etc. (Andjelic et al., 2010). Peng and Luo argue that corporations and other enterprises have had to develop unique strategies to cope with the broad scope and rapidity of economic and political change in emerging markets (Peng \&, Luo, 2000). Also, government and societal influences are stronger in these emerging markets than in developed markets. In addition, emerging markets are characterized by high levels of product diversion within or between countries, widespread product counterfeiting, and opaque power and loyalty structures within complex networks of local business and political players (Arnold \& Quelch, 1998). Each one of these characteristics has added to the emerging economic dominance of the corporation (Tudway \& Pascal, 2006). Today, as B. Melnikas states (Melnikas, 2005) it may be stated that the countries of Central and Eastern Europe have acquired valuable experience in responding to radical changes as well as to challenges of globalization, internationalization, and societal transformations. Also, he states importance of the "innovative character of transitions (meaning that any transition accumulates some novelty). In the transition period, the innovative potential is intensely developed by providing the conditions for innovative activities. The novel character of transitions may be expressed in two ways: first, the conditions are created for adapting well-known models and solutions to some situation in a new way. In this case, they are considered to be innovative. Second, completely new, previously unknown models and solutions are made. In this case, these newly created patterns, having no analogues, are considered to be innovations. The development of two types of novelties in the transition period emphasizes the importance of innovative activities for the countries of Eastern and Central Europe ".

Although different in some aspects, Serbia, Bosnia and Montenegro have a common denominator being countries in EU integration process. In addition, they have emerging economies and are seen as rather interesting investment opportunity. In this paper potential differences between the joint stock companies and other companies from the research sample are examined, in terms of selected innovation factors of companies on emerging markets of Serbia, Bosnia, and Montenegro. Observed similarities and differences are the 
result of the implemented research. This paper will be significant both for academic and professional community with special emphasizes to the identification of advantages and pitfalls of the legal form of the company, regarding company's innovativeness. The remainder of this paper is organized as follows: Section 2 gives theoretical background; Section 3 provides an overview of the methods that were used, highlighting the main characteristics of each. Section 4 describes the results in detail, which is followed by the discussion and conclusion.

\section{Theoretical background}

\subsection{Legal forms of economic activity organisation}

The selection of a company legal form in which its members achieve their interests, within the above legal systems, is free. The division of the companies by their special characteristics facilitates the decision which legal form to select. Due to common characteristics, the companies may be grouped into different types. In such manner, the similarities and differences among individual company types are better perceived, and the stakeholders are facilitated to select the company they want to use to satisfy common objective because of which they associate (Barbić, 2008). Comparative analyses perceive two most frequent divisions of companies (Boyle \& Birds, 1989). The first division of the companies is the one whose criterion includes the existence of legal personality. Within the legal systems of Serbia, Bosnia, and Montenegro, all of the companies have the characteristic of legal entity i.e. legal personality, excluding entrepreneur who is private individual and is not included in the notion of company. In contrast to this, in the laws of Germany, Austria, Switzerland, and Italy public companies and limited partnership are not legal entities though they have "firm" and though they are recorded in register. For the companies which are legal entities, it is important to emphasize that a new legal entity is created by association separated from the personality of its members. For the companies not having the capacity of legal entity, it is important that when a company originates, new legal entity does not originate. Its existence rather depends on members and it is closely related to them, because they comprise it. Another division which is, at the same time, generally theoretically accepted in almost all counties acknowledging companies, is the division to proprietorship, partnership, and corporation. The division in this group is made with regard to basic characteristics of such company groups.

The proprietorships and partnerships are such companies where personal relation of the members is the basic principle of their organisation. The company "stands and falls" with its members, death or withdrawal of a member results in, as a rule, the company cessation. In some laws, the proprietorships and partnerships remain only agreements (with certain status capacity) and they do not have the capacity of legal entity. Contrary to this, in the laws of Serbia, Bosnia, and Montenegro, the proprietorships and partnerships have the capacity of legal entity. Therefore, the company assets are its assets rather than that of its members. Besides, due to the character of the relation in the proprietorships and partnerships, company members are liable for the company obligations in unlimited and joint manner. Typical proprietorships and partnerships include general partnership and limited partnership. 
Contrary to the proprietorships and partnerships, another group includes corporations with legal personality, which is independent from its members. They have legal personality within all rights. The company members are not mutually related as in case of the proprietorship and partnership, but each of them individually is related with the company itself. The company assets are independent in relation to the member assets, thus, only the company with its assets is liable for the company responsibilities. Corporations are very favourable form for additional obtaining of capital on the market. Corporations are managed by special company management independent from the change of the company members. Basic type of the corporation is joint stock company, but also limited liability company is included in this group.

In addition to the above legal forms of companies, new forms of performing economic activities were also developed in the most developed market economies of the twentieth century (Gower \& Davies, 2008). Since the research implemented on the emerging market is shown in this paper none of new organisation forms is known either in formal or informal form. The companies in these areas are determined by numerous clauses (general partnership, limited partnership, limited liability company, and joint stock company), thus another type of the company could not be created except those prescribed in the law.

\subsection{Innovation activities on the emerging markets}

Through emerging economies, financial markets are under-developed, thus, neither asserting strong pressures for firms to be efficient nor enabling the efficient sales of assets (Khanna \& Palepu, 1997; 2000). Transition economies are characterized by an array of specific features and characteristics, given that in these economies the degree of changes both on micro and macro spheres - are manifested more intensively, market fluctuations are more significant and their effects are more obvious (Andjelic\&Djakovic, 2012). Selected countries from research area are in a process of transition. They build a market economy and strive to create a new structure of the economy that is more in accordance with the world and European market demands (Bjelic, 2005). The results of Global Innovation index (2013) show that the selected countries from the research sample are not good at innovation. Montenegro is $44^{\text {th }}$, Serbia $54^{\text {th }}$, and Bosnia and Herzegovina $65^{\text {th }}$ in the list of 142 countries. Obviously, there are no good conditions to create a critical mass of innovative companies. These countries also have problems with the efficiency of legal system, especially in the area of intellectual property protection; foreign direct investments are an extremely important channel for integration of innovations, new processes and technologies; companies' spending on R\&D is very low, financial market is not developed and venture capital is not available; intensity of local competition is very low, and university-industry collaboration in R\&D is not developed. Bosnia performs very low in human resources aspects, innovative culture, and capacity for innovation (Tekic et al., 2011).

Stimulus to innovate is an imperative in innovative economy, where knowledge, as a basic resource, becomes the basis of competitive advantage. Being innovative company means to increase the rate at which new products/services valued by customers are efficiently placed on the market every year (Borocki et al., 2013). Modern, innovative companies at any given time have more, not completely and specifically defined, targets to be implemented, and each of the targets may be realised in a different manner. Therefore, a 
request is set upon the innovative company to use certain models of the strategic planning - in a new manner or within new areas of the operation.

The innovative company structure is considered an integrative system ensuring continuing connection of the company with its environment. It should ensure any integrative qualities as a necessary precondition for any innovative process stages, flexibility, and adaptability to the various technologies and changing environment, as well as the capability of development in order for the company to face changeable needs of life stage cycles occurring while the company grows and matures. In competitive business context innovation has become a key factor for the successful performance of most organizations and top management is important in promoting a strategy of innovation by the process of influence (Camelo et al., 2010). Companies have to create new ideas and turn them into innovative products and processes. Appropriate innovation management strategies, including creation of various kinds of alliances with other business entities, need to be adopted within company. The innovation drive level varies among various countries, as well as from one industrial sector to another. For a particular society as a whole, this level can directly be linked to the society's GDP (Gumilar, 2011). As Jakubavicius et all states (Jakubavicius et al., 2011), the features of innovative enterprises are: orientation to changes, constant information channels, team work, decentralisation and risk as the self explanatory thing, the defence of the bureaucracy and formalism, and the promotion of initiative. Innovation in a modern business context is therefore about organizations' ability to provide the extra dimension of quality that will differentiate a product or service, through newness and originality.

\section{Method}

The research covered 126 companies from Serbia, B\&H and Montenegro. In the effort to have a sample as representative as possible, the selected companies were differing in their size, legal form, organisation form, belonging to economic branch (economic sector), location, activity, and ownership. The questionnaire used for data collection was created according to the characteristics of the operation on the emerging markets and it is a significantly modified questionnaire in comparison to the original one (Borocki, 2009). Small and medium enterprises (SMEs) are significantly represented within the sample structure, at around 49\%. Individual statistical analyses below will be made especially for sub-sample: SMEs, and for the sub-sample accounting for joint stock companies. The overview of the structure is presented in Table 1.

\begin{tabular}{|r|c|c|}
\hline Economic operators & No. of companies within the sample & Percentage \\
\hline Joint stock companies & 31 & 26.72 \\
\hline Limited liability companies & 56 & 48.28 \\
\hline Entrepreneurs & 8 & 6.90 \\
\hline Public and utility companies & 10 & 8.62 \\
\hline Other & 11 & 9.48 \\
\hline & 116 & $100 \%$ \\
\hline
\end{tabular}

Tab. 1. Sample structure in terms of legal form of organization.

Limited liability joint stock companies (49\%) and/or joint stock companies (27\%) are significantly predominant in relation to the form of company organisation. 
Since it was necessary to decrease the number of the factors within the existing analysis for the evaluation of the company strategic performance, as well as to decrease the complexity of the existing model, the methods of the data analysis ensuring this were selected. The data were processed within the strategic programme packages of Statistica and SPSS.

In the first analysis stage, the companies and factors with more than $5 \%$ of the missing data were excluded from the further processing. Little's test was applied to the remaining data to verify the randomness of the missing data distribution, and, afterwards, when it was determined that the missing data were fully randomly distributed, they were replaced with the procedure of maximum authenticity i.e. EM (Expectation Maximization) built in the module for the analysis of the missing data of the SPSS programme package.

Standard descriptive statistical indicators for all of the variables were calculated arithmetic means, standard deviations, and skewness and kurtosis indicators for each of the continuing variables, and frequencies for categorical variables.

Standard SPACE model adequacy was reviewed using confirmative factor analysis within module for modelling using structural equations (SEPATH) of the Statistica statistical programme package.

The questionnaire set up through the revision of the modified SPACE analysis (significance domain) covers seven metrical scales in its final version (instead of four within the modified SPACE model), and the characteristics of the metrical scales, including a brief description of Alpha coefficient, are presented in Table 2.

Answers to 71 items of the modified SPACE questionnaire (instead of original 80) within the significance domain were included in the analysis. After the initial exclusion of individual variables, some measurement characteristics of the newly formed scales were verified. The significance domain was selected as a decisive aspect for the model modification, primarily because of its space orientation to the variables which may be significant for the interviewees in the future. Latent structure of the space of measuring the modified SPACE model significance and value was reviewed using the analysis of the main components. This procedure was selected by reason of predominantly explorative nature of this study and tendency to avoid the risk of excluding potentially useful variability from the analysis. With the aim of determining the latent structure of the common space of summary scores on the scales of the modified SPACE model, the analysis of the main components was implemented. Main kept components were rotated in Promax position. Promax rotation was made and the most interpretable solution was selected (the solution with 7 main components). For each scale, Kronbah alpha coefficient of reliability was calculated (Table 2). The same was done within the value domain.

\begin{tabular}{|l|l|l|l|}
\hline No. & Scale name & Brief scale description & Alpha* \\
\hline
\end{tabular}




\begin{tabular}{|c|c|c|c|}
\hline 1 & $\begin{array}{l}\text { Company } \\
\text { innovation from } \\
\text { product/service } \\
\text { aspect }\end{array}$ & $\begin{array}{l}\text { The factors relating to the innovation and } \\
\text { development processes at the company as well } \\
\text { as to the operational and development aspects of } \\
\text { client relation: Product development, operation } \\
\text { technology, and human resources, Product } \\
\text { quality and originality, Product delivery } \\
\text { deadlines, Available know-how, etc. }\end{array}$ & .9276 \\
\hline 2 & $\begin{array}{l}\text { Client orientation } \\
\text { and reputation in } \\
\text { the external } \\
\text { environment }\end{array}$ & $\begin{array}{l}\text { The factors covering the operational activities of } \\
\text { client relation evaluate the company acceptance by } \\
\text { the clients and business partners: Timeliness of } \\
\text { taking corrective actions, Flexibility in relation to } \\
\text { client requirements, Company image, } \\
\text { Product/service prices in relation to major } \\
\text { competitors, Credibility with the business partners, }\end{array}$ & .8623 \\
\hline 3 & $\begin{array}{l}\text { Market growth } \\
\text { potentials }\end{array}$ & $\begin{array}{l}\text { The factors relating to the characteristics of the } \\
\text { market on which company operates: Market } \\
\text { growth rate, Market size, Demand for product, } \\
\text { Possibility of new market opening, Demand } \\
\text { stability, Possibility of placing the same service } \\
\text { type in high number. }\end{array}$ & .7743 \\
\hline 4 & $\begin{array}{l}\text { Financial } \\
\text { potential of } \\
\text { company } \\
\text { operation }\end{array}$ & $\begin{array}{l}\text { The factors relating to the financial aspects of } \\
\text { company operation describing the internal } \\
\text { components of company financial potential: Costs } \\
\text { stability, Working capital coefficient, Timeliness of } \\
\text { the payment of short-term liabilities, Level of cash } \\
\text { inflow in terms of self-finance. }\end{array}$ & .7894 \\
\hline 5 & $\begin{array}{l}\text { General } \\
\text { characteristics of } \\
\text { economic } \\
\text { segment }\end{array}$ & $\begin{array}{l}\text { The factors relating to the nature of the economic } \\
\text { segment and/or economic/ind. branch within which } \\
\text { company operates: Energy price changes, } \\
\text { Economic sector energy dependence, Raw material } \\
\text { availability, Possibility of manufact. in large series, }\end{array}$ & .7415 \\
\hline 6 & $\begin{array}{l}\text { Economic } \\
\text { segment } \\
\text { profitability } \\
\text { (Aspect of } \\
\text { competitiveness - } \\
\text { econ. segment } \\
\text { volatility) }\end{array}$ & $\begin{array}{l}\text { The factors relating to company's competition } \\
\text { for selected main product and/or market: } \\
\text { Number of competitors within the economic } \\
\text { sector, Pressure of the competition within the } \\
\text { economic segment, Number of product variants } \\
\text { within the economic segment, Changes in the } \\
\text { prices of competitive products, etc. }\end{array}$ & .7677 \\
\hline
\end{tabular}




\begin{tabular}{|l|l|l|l|}
\hline 7 & $\begin{array}{l}\text { The factors relating to the environment } \\
\text { components determined through the impact of } \\
\text { government and rules of operation prescribed at } \\
\text { the government level, which may not be } \\
\text { impacted or controlled by company: Changes in } \\
\text { legal aspects of } \\
\text { the external } \\
\text { environment }\end{array}$ & $\begin{array}{l}\text { regulations, laws, Government relation to } \\
\text { economic branch, Economic growth in the } \\
\text { country, Tax liabilities, Inflation rate, etc. }\end{array}$ & .7638 \\
\hline
\end{tabular}

Tab. 2. Metrical scales developed through the revision of the modified SPACE model (Borocki, 2009) within the significance domain.

With the aim of determining the structure of the differences between joint stock companies and other companies within the dimensions of the modified SPACE model, canonical discriminative analysis was applied. Grouping (criterion) variable included the belonging to the group of joint stock companies i.e. other companies, and the set of quantitative (predictor) variables accounted for the summary scores on the scales of the modified SPACE questionnaire.

\section{The research results and conclusion}

\subsection{Company taxonomy within the space of the scores on the dimensions of the modified SPACE model}

With the aim of determining the company taxonomy within the space of the scores on the dimensions on the modified SPACE model, cluster analyses were implemented. In the first analysis stage, on the matrix of squared Euclidean distances among the companies in the space of the standardised summation scores on the newly formed questionnaire scales, the hierarchical cluster analysis was implemented, using Ward procedure. Based on simultaneous consideration of the agglomeration chart and dendogram, the decision was made that the two-cluster solution is optimal. After the determination of the optimal number of the clusters, hierarchical cluster analysis was implemented (k-means procedure) (Garson, 2008; Tenjović, 2000) with two pre-set clusters. This analysis procedure was selected because it ensures the transfer of the respondents from one cluster to another until the most stable solution is achieved.

\begin{tabular}{|l|l|l|}
\hline & Frequency & Percentage \\
\hline 1 & 56 & 48.3 \\
\hline 2 & 60 & 51.7 \\
\hline Total & 116 & 100.0 \\
\hline
\end{tabular}

Tab. 3. Number of respondents in the clusters.

The clusters were identified using the canonical discriminative analysis, where the grouping (criterion) variable was belonging to a cluster, while the set of the 
quantitative (predictor) variables accounted for the standardised scores on the scales of the modified SPACE questionnaire.

\begin{tabular}{|l|l|l|l|l|}
\hline Function & Inherent value & Variance percentage & $\begin{array}{l}\text { Cumulative } \\
\text { percentage }\end{array}$ & $\begin{array}{l}\text { Canonical } \\
\text { correlation }\end{array}$ \\
\hline 1 & 1.788 & 100.0 & 100.0 & .80 \\
\hline
\end{tabular}

Tab. 4. Discriminative function characteristics.

\begin{tabular}{|l|l|l|l|l|}
\hline Function & Wilks' Lambda & Chi-square & df & $\mathrm{p}$ \\
\hline 1 & .359 & 113.303 & 7 & .00 \\
\hline
\end{tabular}

Tab. 5. Discriminative function significance testing.

The discriminative function is statistically significant at the level $p<0.001$. The height of the canonical correlation coefficient $\left(R_{c}=0.8\right)$ points out high intensity of differences between the groups.

\begin{tabular}{|l|l|}
\hline & Function \\
\hline Client orientation and reputation in the external environment & .552 \\
\hline Financial potential of the company & .551 \\
\hline Company innovativeness (product/service aspects) & .548 \\
\hline General characteristics of industrial segment & .547 \\
\hline Profitability of industrial segment (competitor's aspects, volatility) & .523 \\
\hline Market growth potential & .485 \\
\hline Political and legal aspects of external environment & .230 \\
\hline
\end{tabular}

Tab. 6. Discriminative function structure matrix.

All of the dimensions of the revised SPACE model significantly correlate with the discriminative function, excluding the seventh (Political and Legal Aspects of External Environment). The contributions of the scores on the remaining dimensions are of uniform height. Since the content of the discriminative function predominantly relates to the elements which may be controlled and/or over which the company has got certain impact degree, it may be hypothetically interpreted as Company Operation Controllability. It is noticeable that the seventh component covering the external environment instability factors, which the company may not impact or control, fails to provide significant contribution to the discriminative function.

\begin{tabular}{|l|l|}
\hline Cluster & Function \\
\hline & 1 \\
\hline 1 & -1.372 \\
\hline 2 & 1.281 \\
\hline
\end{tabular}

Tab. 7. Group centroids.

The members of the first cluster achieve low scores on the discriminative function, and the members of the second cluster achieve high ones. Virtually, this means that the 
members of the first cluster assign the significance to the innovation and development processes at the company, client relations, and reputation in the environment, key financial indicators, economic segment profitability, as well as to its characteristics (growth potential) and market characteristics to a significantly lower extent while the members of the second cluster assess the significance of such dimensions as significantly higher. The members of the second cluster achieve high scores on the controllable factors of the company operation. Accordingly, the first cluster was interpreted as passive (conservative, defensive), and the second cluster as proactive (more aggressive, competitive). It may be concluded that the proactive companies using the chances in the external environment belong to the second cluster. The companies belonging to the first cluster do not have such characteristics.

\begin{tabular}{|l|l|l|l|l|l|}
\hline & & \multirow{2}{*}{ Cluster } & \multicolumn{2}{|l|}{$\begin{array}{l}\text { Anticipated membership in the } \\
\text { group }\end{array}$} & Total \\
\cline { 4 - 6 } & & & 1 & 2 & \\
\hline Original & Number & 1 & 55 & 1 & 56 \\
\hline & & 2 & 4 & 56 & 60 \\
\hline & $\%$ & 1 & 98.2 & 1.8 & 100.0 \\
\hline & & 2 & 6.7 & 93.3 & 100.0 \\
\hline
\end{tabular}

Tab. 8. A posterior classification results.

A posterior classification suggests that, based on the discriminative function, $95.7 \%$ of the entities are accurately recognised. Only one company from the first and four companies from the second cluster were incorrectly allocated. The accuracy of the company recognition (their belonging to certain cluster) is rather high: for the first cluster it amounts to $98.2 \%$ and for the second cluster $93.3 \%$.

4.2.2 Differences between joint stock companies and other companies in terms of innovation expression

\begin{tabular}{|l|l|l|l|l|l|}
\hline & $\begin{array}{l}\text { JSC joint stock } \\
\text { companies }\end{array}$ & $\mathrm{N}$ & Mean & $\begin{array}{l}\text { Std. } \\
\text { Deviation }\end{array}$ & $\begin{array}{l}\text { Std. error } \\
\text { Mean }\end{array}$ \\
\hline INNOVATIVENESS & .00 & 85 & 44.3993 & 10.50881 & 1.13984 \\
\hline & 1.00 & 31 & 49.3710 & 7.61902 & 1.36842 \\
\hline
\end{tabular}

Tab. 9. Descriptive statistics.

Hierarchical cluster analysis is one of the analyses applied on such modified SPACE model of strategic planning with the aim of determining the optimal number of the clusters. Afterwards, non-hierarchical cluster analysis was applied to achieve the most stable solution. The results demonstrated that the two clusters obtained in this manner were very different (since the correlation coefficient is $R_{c}=0.8$ ). Considering the cluster structure, it may be concluded that the companies belonging to the first cluster are indeed non-innovative, passive (with probably defensive or conservative strategic performance) while the 
companies in the second cluster are focused to the proactive activity (with most probably aggressive or competitive strategic performance).

The accuracy of recognising the companies within these two clusters is very high, and it virtually points out great differences between these two clusters. The number of the companies within each of these clusters is rather equal: there are 55 and 56 companies in the first and second cluster, respectively.

\begin{tabular}{|l|l|l|l|l|l|l|l|}
\hline & \multicolumn{3}{|l|}{$\begin{array}{l}\text { Levin's } \\
\text { variance } \\
\text { homogeneity } \\
\text { test }\end{array}$} & \multicolumn{3}{|l|}{$\mathrm{t}$ - test } \\
\cline { 3 - 9 } & & $\mathrm{F}$ & $\mathrm{p}$ & $\mathrm{T}$ & $\mathrm{df}$ & $\mathrm{p}$ & $\begin{array}{l}\text { AS } \\
\text { difference }\end{array}$ \\
\hline \multirow{2}{*}{ INNOVATIVENESS } & $\begin{array}{l}\text { Equal } \\
\text { variances }\end{array}$ & 2.514 & .116 & -2.410 & 114 & .018 & -49.716 \\
\cline { 2 - 9 } & $\begin{array}{l}\text { Unequal } \\
\text { variances }\end{array}$ & & & -2.792 & 73.444 & .007 & -49.716 \\
\hline
\end{tabular}

Tab. 10. T test for independent samples.

The difference between joint stock companies and other companies in terms of the expression of the innovativeness dimension is significant at the level $p<0.05$. Joint stock companies achieve higher scores on this dimension.

Observing the sample structure, and owing to certain specifics of the joint stock companies, the sub-sample of such companies was additionally tested using chi-square test. The conclusion was drawn that a high number of the companies having such legal form of organisation assign significance to the innovation development, clients, and other substantial aspects of the company competitiveness.

\section{Conclusions}

The characteristics of joint stock company by which it, at the same time, differs from other companies include that it is the legal entity, having legal personality; that it is company which is actually corporation; that its core capital is divided into shares, and that shareholders are not liable for the company's obligations.

The above characteristics of joint stock companies in comparison to other forms of organisation are benefits for the performance on the market. Due to its characteristics, this organisation form is appropriate for gathering an unlimited number of people to perform even the most complex economic activities. At the same time, it means that this organisation form is appropriate for investing and/or financial capital dispersion to a high number of persons while avoiding economy atomising. Contrary to other legal forms, with joint stock companies, operation management is separated from company members. It ensures high professionalization of management and engagement of the experts who are entrusted invested funds to operate with them. With a joint stock company, a member receives a share as a counter value for what he has invested in the 
company and what becomes company ownership. In this way, the value of the property of what a shareholder has taken out of his property is doubled: the joint stock company into which a stake has been entered has got one value, and the shareholder who has acquired the shares has got the second one (Barbić, 2008). Selling the shares on the securities market, shareholder easily exits the company and thus gets back the stake value while not decreasing company property. The circumstance that the participations are expressed in the shares which are easily transferable ensures facilitated movement of capital and its acquisition (through new share issuance) both within one country and internationally.

The above advantages underpin the selection of new organisation form, but there are also some disadvantages. In comparison to the general partnerships and limited liability companies, there is a high degree of formality with joint stock company (especially public call of foundation and high costs of incorporation as well as operation). In addition, the rules on managing bodies (executive and non-executive directors), convoking of general meeting, rules on minority shareholders, make this form of economic operation one of the most complex.

The highest correlation degree within the joint stock company sub-sample was achieved with the scale whose structure mostly accounts for the factors indicating the political and legal aspects of external environment (impact of the government which, with its activities, demonstrates what significance joint stock companies assign to that). General characteristics of economic segment as well as client orientation and reputation in external environment are not of great significance for joint stock companies. This may pose a problem on a long-term scale since any client neglect leads the company to a very deprived situation. In terms of the innovation dimension distinction (the first Promax components within the significance domain), joint stock companies assign more significance to the innovation than other companies from the sample do, which was tested using t-test for independent samples. If the sample structure of the first Promax component is considered (Table 2), the factors the joint stock companies assign the highest significance to will be seen, which are as follows: product/service development, operation technology development, human resources development (indirectly measured through the investment level and continuity of investment in development), followed by service originality and quality, available know-how, etc. At first glance, the degree of innovation should not be affected by the legal form of the company, but the findings show that professional management and stable financial environment make innovation in the specified environment more visible.

Considering how the companies from the sample evaluated the innovation factors proposed in the existing (analysed) SPACE model, the following may be noticed: The joint stock companies show somewhat better results on the component indicated as the Company Innovation and Reputation in External Environment (scale name 1 and 2 from Table 2). It means that joint stock companies assign somewhat higher significance to innovation than other companies do. Since $59.48 \%$ of the companies within the structure of this sub-sample are service companies, it is likely that their innovations result from process innovation (Borocki et al., 2011).

Since the first Promax component named: Company innovativeness (product/service aspects) includes only a few aspects of innovativeness (e.g. product 
development, operating and human resources technologies, product quality and originality, product delivery dates, available know-how, etc.), a larger group of key factors must be included in a future research in order to give a more precise picture of innovativeness of the company. It is useful to take into consideration and to analyse the results of research in which authors attempted to quantify innovation by evaluating outputs through the enumeration of patents, through R\&D inputs, through impacts of innovation activity or in some other way (Borocki et al., 2010). Additional researches could be directed to determining which shareholders have a major share at such selected companies and whether higher percentage of participation in ownership may be linked to these key elements. Also, it will be interesting to analyze administrative innovations which will probably have an impact on this kind of companies, more than on manufacturing ones (Palcic et al., 2014).

The legal form of the company, especially joint stock company, presents a significant challenge for empirical examination of company's innovative factors. Further, in that way it is possible to make a comparative of SMEs and joint stock companies which are characterized by complex and in some way rigid organizational structure, strong management and more stable financial background.

\section{Acknowledgement}

The authors acknowledge the financial support of the Ministry of Education and Science of the Republic of Serbia, within Project No 47028.

\section{References}

Andjelic, G., Djakovic, V., Radisic, S. (2010). Application of VaR in emerging markets: A case of selected Central and Eastern European countries, African Journal of Business Management (AJBM), Vol. 4, No. 17, pp. 3666-3680

Andjelic, G., Djakovic, V. (2012). Financial Market Co-Movement between Transition Economies: A case study of Serbia, Hungary, Croatia and Slovenia, Acta Polytechnica Hungarica, Vol.9, No.3, pp.115-134.

Arnold, D. J., Quelch, J. A., New strategies in emerging economies, Sloan Management Review, 1998, 40(1), pp. 7-20

Barbić, J. (2008). Pravo društava - Opći dio, knjiga 1, Organizator, Zagreb, pp. 153-163.

Bjelic, P., (2005). Trade policy of the European Union as a factor of regional trade integration in Southeast Europe, Centre for the study of global governance London school of econ. and political science, London, http://www.lse.ac.uk/Depts/global

Boyle\&Birds. (1989). Company Law, Jordan\&Sons Limited, Bristol

Borocki, J., Cosic, I., Lalic, B., Maksimovic, R. (2011) Analysis of company development factors in manufacturing and service company: a strategic approach, Strojniški vestnik - Journal of Mechanical Engineering 57(2011) 1, pp. 55-68, UDC 658.51:005.21

Borocki, J., Jocic, J., Senk, V. (2010). Analysis of innovation factors of micro and small companies: a strategic approach, Proceedings of International Conference for 
Borocki, J.; Djakovic, V.; Buncic, S. \& Buncic, S.: Analysis of Innovation Factors ...

Entrepreneurship, Innovation and Regional Development - ICEIRD 2010, Novi Sad, Republic of Serbia

Borocki, J., (2009). Razvoj modela strategijskog planiranja u funkciji inovativnosti preduzeća (doktorska disertacija), Univerzitet u N. Sadu, Fakultet tehničkih nauka, Novi Sad

Borocki, J., Cvijic, M., Orcik, A. (2013). Measuring Organizational Innovativeness. Chapter VIII in Engineering Management - Challenges for the Future, pp. 147-164, H.-J. Bullinger \& D. Spath (Eds.), published by Faculty of Technical Sciences (Novi Sad, Serbia), Fraunhofer IAO (Stuttgart, Germany) and DAAAM International (Vienna, Austria), ISBN 978-3-902734-01-3

Camelo, C., Alles, M. F., Hernandez, A. B. (2010). Strategic consensus, top management teams, and innovation performance, International Journal of Manpower, 31(6), pp.678-695 Enderwick, P. (2008). Quality assurance and upgrading in global supply chains: implications for management in a transition economy, Thunderbird International Business Review, 2008, Vol. 50, No. 4, pp. 217-30

Garson, G. D., Statnotes, (2009). Topics in Multivariate Analysis, downloaded on 02 April 2009 from http://faculty.chass.ncsu.edu/garson/pa765/statnote.htm

Gower and Davies, (2008). Principles of modern company law

Gumilar, V., Zarnic, R., Selih, J. (2011). Increasing Competitiveness of the Construction Sector by Adopting Innovative Clustering, Inzinerine Ekonomika Engineering Economics, 22(1), pp.41-49

Hoskisson, R.E., Eden, L., Lau, C.M. and Wright, M. (2000). Strategy in emerging economies, Academy of Management Journal, Vol. 43 No. 3, pp. 249-67

Jakubavicius, A., Jucevicius, R., Jucevicius, G., Kriaucioniene, M., Kersys, M. (2008). Inovacijos versle: procesai, parama, tinklaveika, Vilnius, 180

Khanna, T., Palepu, K. (1997). Why focused strategies may be wrong for emerging markets, Harvard Business Review, 75(4), pp. 41-55

Khanna, T., Palepu, K. (2000). Is group affiliation profitable in emerging markets? An analysis of diversified Indian business groups, Journal of Finance, 55, pp.867-892

Melnikas, B., (2005). Transition economy: urbanization, the processes of creation and accumulation of property - Ekonomika, ISSN 1392-1258, pp. 72-94

Peng, M. W., Luo, Y., (2000). Managerial ties and firm performance in a transition economy: The nature of a micro-macro link, Academy of Management Journal,43: pp. 486-501

Tekic, Z., Cosic, I., Borocki, J., Lalic, D. (2011). How Innovative South East Europe Is?, Proceedings of International Conference for Entrepreneurship, Innovation and Regional Development - ICEIRD, Ohrid, FYR of Macedonia,

Tenjović, L. (2000). Statistika za psihologe - priručnik, Beograd, Centar za primenjenu psihologiju

Tudway, R., Pascal, A.M. (2006). Corporate governance, shareholder value and societal expectations, Corporate Governance, Vol. 6, No. 3, pp. 305-316 http://www.globalinnovationindex.org/content.aspx?page=gii-full-report-2013\#pdfopener 